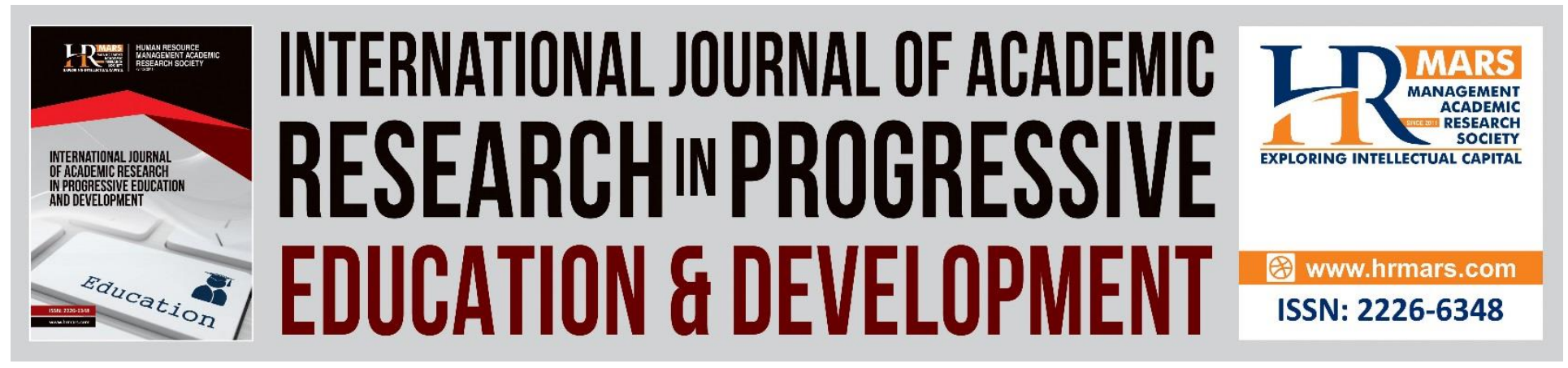

\title{
The Impact of E-Learning on Academic Performance: Preliminary Examination of King Khalid University
}

\author{
Udjo Eseroghene Franklin, Amal Ahmad Nahari
}

To Link this Article: http://dx.doi.org/10.6007/IJARPED/v7-i1/3903

DOI: $\quad 10.6007 /$ IJARPED/v7-i1/3903

Received: 01 Feb 2018, Revised: 02 Mar 2018, Accepted: 19 Mar 2018

Published Online: 22 Mar 2018

In-Text Citation: (Franklin \& Nahari, 2018)

To Cite this Article: Franklin, U. E., \& Nahari, A. A. (2018). The Impact of E-Learning on Academic Performance: Preliminary Examination of King Khalid University. International Journal of Academic Research in Progressive Education and Development, 7(1), 83-96.

\section{Copyright: (C) 2018 The Author(s)}

Published by Human Resource Management Academic Research Society (www.hrmars.com)

This article is published under the Creative Commons Attribution (CC BY 4.0) license. Anyone may reproduce, distribute, translate and create derivative works of this article (for both commercial and non-commercial purposes), subject to full attribution to the original publication and authors. The full terms of this license may be seen

at: http://creativecommons.org/licences/by/4.0/legalcode

Vol. 7, No.1, January 2018, Pg. 83 - 96

http://hrmars.com/index.php/pages/detail/IJARPED

JOURNAL HOMEPAGE

Full Terms \& Conditions of access and use can be found at http://hrmars.com/index.php/pages/detail/publication-ethics 


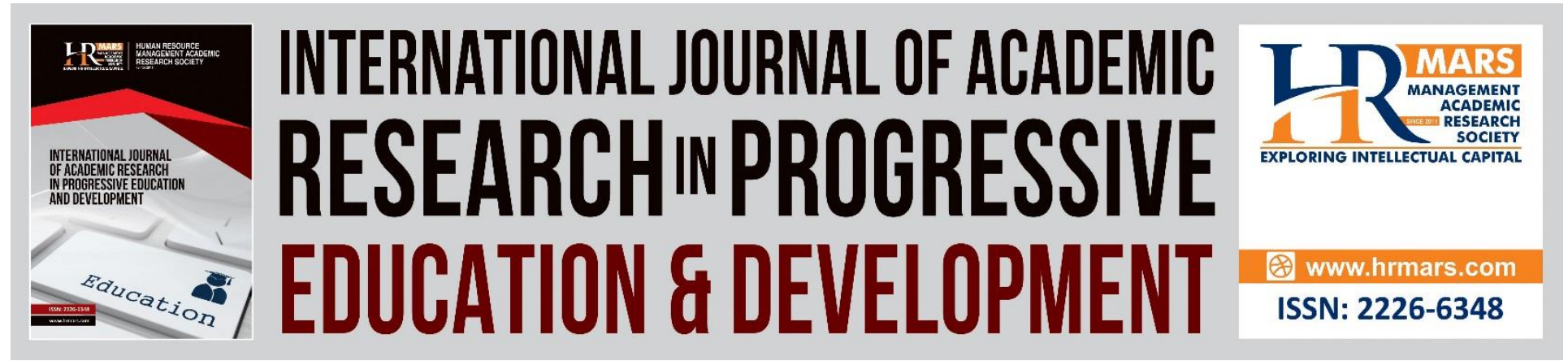

\title{
The Impact of E-Learning on Academic Performance: Preliminary Examination of King Khalid University
}

\author{
Udjo Eseroghene Franklin \\ Department of Business Administration, Ibn Rushd College of Management Sciences, Abha- \\ Saudi Arabia \\ Email: ese.udjo@ibnrushd.edu.sa
}

\begin{abstract}
Amal Ahmad Nahari
Department of Business Administration, King Khalid University, Abha-Saudi Arabia Email: a.analhari2@hotmail.com
\end{abstract}

\begin{abstract}
The study assessed the impact of electronic learning on academic performance in Saudi Arabia. Precisely, we evaluated the influence of web-based learning on academic staff at the King Khalid University utilizing a sample of 163 respondents as our unit of analyses. Structural equation modeling (SEM) was employed to evaluate the impact of the exogenous variables on the endogenous variables. Furthermore, SEM was used to test the hypothesized model. The results indicate that our hypothesized model reasonably fitted the data collected and five of the nine hypotheses were refuted. The study confirmed that acceptance for online teaching (AFOT), Technical competency (TC) and synchronous (SYNC) lectures have indirect influence on performance of academic staff (PERF_ACAD_STAFF). Additionally, acceptance for online teaching (AFOT) and Technical competency (TC) have direct impact on performance of academic staff (PERF_ACAD_STAFF).

We concluded that our empirical model presented in figure 3 should guide KKU in designing its E-learning initiatives. This is so because it will enable KKU students to achieve similar learning outcomes that are comparable to traditional classroom format.

Keywords: E-learning, Online teaching, E-learners, web technologies, Performance, Academic Staff
\end{abstract}

Introduction 
Vol. 7, No.1, January 2018, E-ISSN: 2226-6348 @ 2018 HRMARS

E-Learning is known as Web-based learning, online learning, distributed learning, computerassisted instruction or Internet-based learning. It is primarily a web-based system of education that makes information or knowledge available to users or learners. On the whole, E-learning disregards geographic proximity.

The application of web-based technologies for educational purposes has increased principally because the costs of adopting such technologies have dramatically decreased. Given this fact, universities are taking advantage of web- based learning and they are utilizing it to complement the face-to-face or traditional approach to learning. King Khalid University (KKU) has adopted the E-learning approach to complement its traditional face-to-face method of teaching and learning. In order to improve academic quality, effectiveness and efficiency of E-learning at KKU, the university relies on the blackboard learning system which it structured into three levels to suit different types of learning needs. The three structural levels are: the supportive, blended and full E-learning. Although KKU has recognized the importance of the role of E-learning as an integral part of its educational process, there are challenges that are impinging on its success. Such challenges have the potential of negatively impacting on the performance of instructors in delivering educational material. It is against this backdrop that the study seeks to examine the impact of E-learning on the performance of academic staff of KKU.

\section{Overview of E-learning}

Tavangarian et al., (2004) observed that E-learning is the adoption of electronic media to facilitate teaching and learning. It utilizes technology to deliver information embedded in educational material to learners situated in diverse geographical areas. E-learning is a substitute method for teaching and learning. It veers away from the conventional classroom lectures (Herrington et al., 2010). Alavi \& Leidner (2001) conceptualized E-learning as a virtual learning environment where different forms of information technologies are used to mediate between the learner and the instructor. E-learning attempts to shift the focus of educational environment away from the physical teacher-student environment while disseminating information. Without regards to distance, instructors utilize new and improved web -based technologies to plan and structure teaching materials (Clark \& Mayer, 2008). According to these authors, e-Learners are subjected to more critical challenges when compared to conventional learners. This is so because the efforts which should have been put in by instructors in motivating and instilling discipline in learners are transferred to the e-learner in an e- learning setting. Stated succinctly, the responsibility of inspiring and encouraging discipline is transferred from the conventional lecturebearing instructor to the learner himself (Liaw, 2008). E- Students are themselves managers and students. They actively manage their learning process while the instructor sets the guidelines (Downes, 2005). E- Students see this as a barrier and it frustrates their learning efforts. The frustration either leads to high drop-out rate or reduced learner satisfaction (Liu et al., 2006).

\section{The Impact of E-learning on Academic Performance}

The impact of E-learning is assessed by ascertaining if students were able to grasp what was delivered or taught to them. Rosenberg et al., (2006) noted that E-learning reduces the ability of students to grasp what is taught or delivered. These authors stressed that there are marked differences between traditional face-to-face learning and E-learning. In a similar vein, Johnson (2005) observed that online teaching strategies have negative impact on academic performance. 
INTERNATIONAL JOURNAL OF ACADEMIC RESEARCH IN PROGRESSIVE EDUCATION AND DEVELOPMENT

Vol. 7, No.1, January 2018, E-ISSN: 2226-6348 @ 2018 HRMARS

On the contrary, Cavanaugh (2001) in a quantitative synthesis of studies of the effectiveness of interactive distance education using video conferencing and telecommunications for K-12 academic achievement emphasized that E-learning and the traditional face-to face approach are comparable. Arguments in favour of E-learning over the traditional or face- to- face learning are those of Barker \& Wendel (2001), Hardaker et al.,(2000), Breuleux et at., (2002), Chambers (2003). The core arguments of these authors are that E-learning have positive impact on students' performance and that it increases the enrollment in academic program. Further to this, Kearsley (2000) opined that online learners achieve the same level of performance and satisfaction which is equal to that of face-to-face setting provided that the quality of instructional materials is similar.

\section{Barriers to E-learning Adoption and Implementation}

Although e-learning is a phenomenal concept, its adoption is not without limitations. The utilization of state-of -the-art technologies does not guarantee that e-learning will result in expected benefits (Ettinger, Holton and Blass, 2006). These authors opined that E-learning is a hindrance rather than a facilitative procedure and substantiated their argument by noting that E-learning does not motivate learners when traditional models of learning are replicated simply by uploading traditional classroom learning materials on web-based platforms. The challenges posed by E-learning have motivated the development of varied pedagogical systems (Roy, 2006). In order to achieve this, various types of collaborators ranging from professional web-based designing firms, content writers and design formulators have begun to act together to create web-based E-learning programs designed to enhance learning through the recognition of various different types of student needs (Roy, 2006). Given that the positive and negative arguments on the impact of E-learning shows inconsistency, we proposed an E-learning model and on the basis of the model series of hypotheses were formulated and tested with a view to taking a standpoint on the subject of discourse.

\section{Proposed Model and Hypotheses}

The proposed E-learning model consists of seven exogenous and two endogenous variables. The exogenous variables are: Acceptance for online learning, Technical competency, Synchronous, Asynchronous, Collaborative methods, online support and E-learning quality standards. The endogenous variables include Reliable infrastructure and Performance of academic staff. Reliable infrastructure mediated between performance of academic staff and the five of the exogenous variables. See figure 1 for the proposed model. 
Figure 1: The Proposed Model

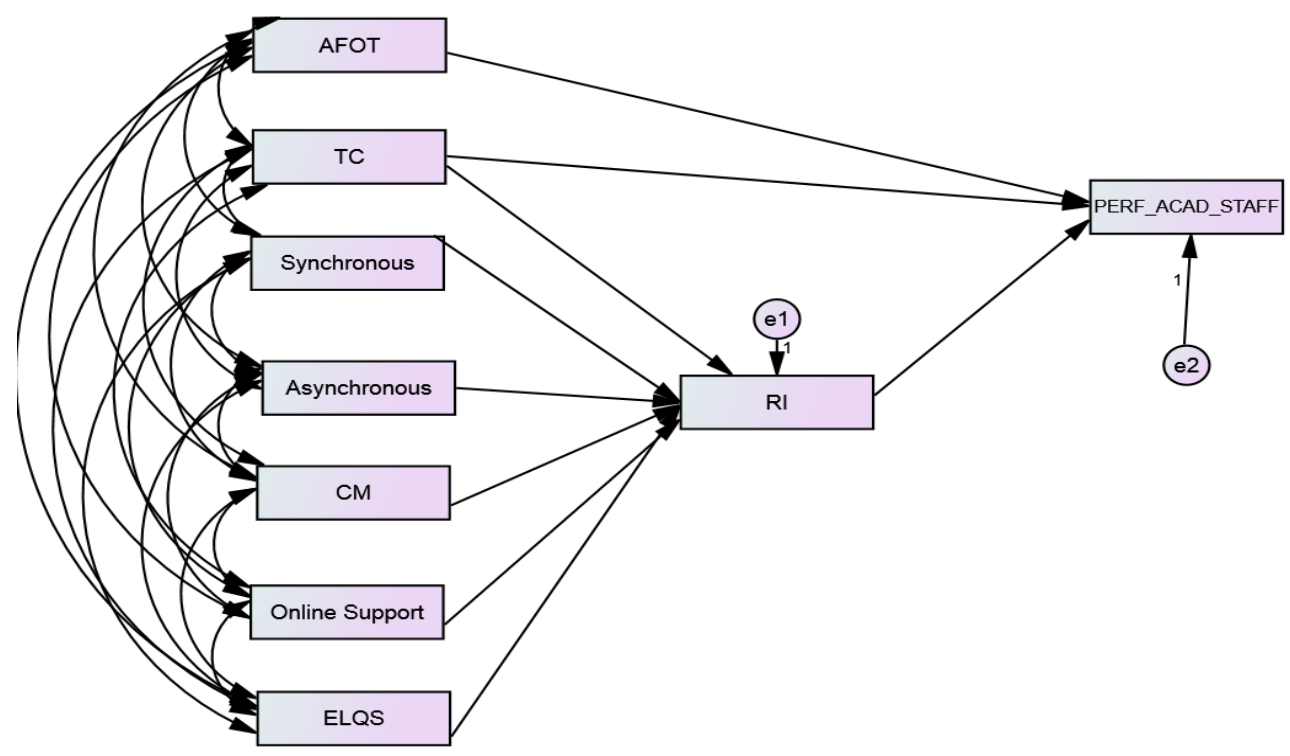

On the basis of the proposed model, the following hypotheses were formulated:

$\mathrm{H} 1$ : Acceptance for online teaching (AFOT) has significant impact on performance of academic staff

$\mathrm{H} 2$ : Technical competency (TC) has significant impact on performance of academic staff H3: Synchronous (SYNC) (real time lecture) has significant impact on reliable infrastructure (RI) $\mathrm{H} 4$ : Asynchronous (ASYNC) (recorded lecture) has significant impact on reliable infrastructure (RI) $\mathrm{H} 5$ : Collaborative methods (CM) has significant impact on reliable infrastructure (RI)

H6: Online support (OS) has significant impact on reliable infrastructure (RI)

H7: E-learning quality standards (ELQS) has significant impact on reliable infrastructure (RI)

H8: Reliable infrastructure (RI) has significant impact on performance of academic staff (PERF_ ACAD_STAFF)

\section{Methodology}

The population for this study is the academic staff at the King Khalid University (KKU). Although the population consists of a total of 4986 academic staff, its demographic spread consist of 2917 male faculty members and 2069 female members. Convenience sampling technique is used to select the 197 respondents that served as the sample size for the study. The initial sample size reduced to 163 respondents because 34 of the returned questionnaire were not found usable due to the reason that they were erroneously completed.

The questionnaire comprised of three parts namely: demographic component, E-learning and academic performance variables. The E-learning and academic performance variables consist of nine constructs that were used to develop the proposed model. The study measured the nine constructs on a 5-point Likert scale that ranged from strongly disagrees to strongly agree. The 
INTERNATIONAL JOURNAL OF ACADEMIC RESEARCH IN PROGRESSIVE EDUCATION AND DEVELOPMENT

Vol. 7, No.1, January 2018, E-ISSN: 2226-6348 @ 2018 HRMARS

nine constructs are: Acceptance for online teaching which we adapted as AFOT, Technical competency adapted as TC, Reliable infrastructures adapted as RI, Synchronous (real time lectures) adapted as SYNC, Asynchronous (recorded lectures) adapted as ASYNC, Collaboration methods adapted as CM, Online Support adapted as OS, E-learning quality standards adapted as ELQS and Performance of academic staff adapted as PERF_ACAD_StAFF. The first seven constructs are exogenous variables while the eighth and ninth are endogenous.

Data analysis underwent three stages. In the first stage, exploratory factor analysis (EFA) was used to assess the variability of the items. The second stage assessed reliability using Cronbach's alpha. A cut- off point of 0.7 was concluded to be a reliable coefficient. The third stage is the structural equation modeling using AMOS (version 22) and Maximum likelihood is chosen as a method of parameter estimation.

\section{Results}

\section{Demographic analysis}

Table 1a: Demographic variable GENDER

\begin{tabular}{|ll|r|r|r|r|}
\hline & Frequency & Percent & Valid Percent & Cumulative Percent \\
\hline \multirow{3}{*}{ Valid } & male & 67 & 41.1 & 41.1 & 41.1 \\
& female & 96 & 58.9 & 58.9 & 100.0 \\
& Total & 163 & 100.0 & 100.0 & \\
\hline
\end{tabular}

Table 1b: Demographic variables Years of Experience

\begin{tabular}{|c|c|c|c|c|c|c|c|}
\hline & & Frequency & Percent & Valid Per & cent & \multicolumn{2}{|c|}{ Cumulative Percent } \\
\hline \multirow{5}{*}{ Valid } & $<5$ & 23 & 14.1 & & 14.1 & & 14.1 \\
\hline & $5-9$ & 45 & 27.6 & & 27.6 & & 41.7 \\
\hline & $10-14$ & 50 & 30.7 & & 30.7 & & 72.4 \\
\hline & $>15$ & 45 & 27.6 & & 27.6 & & 100.0 \\
\hline & Total & 163 & 100.0 & & 100.0 & & \\
\hline \multicolumn{8}{|c|}{ JOB TITLE } \\
\hline & & & Frequency & \multicolumn{2}{|c|}{ Percent } & Valid Percent & Cumulative Percent \\
\hline \multirow{6}{*}{ Valid } & \multicolumn{2}{|c|}{ Professor } & \multirow[b]{2}{*}{25} & \multicolumn{2}{|c|}{4.3} & 4.3 & 4.3 \\
\hline & \multirow{2}{*}{\multicolumn{2}{|c|}{ associate professor }} & & 1 & 5.3 & 15.3 & 19.6 \\
\hline & & assistant protessor & 92 & \multicolumn{2}{|c|}{56.4} & 56.4 & 76.1 \\
\hline & \multicolumn{2}{|c|}{ Lecturer } & 38 & \multicolumn{2}{|c|}{23.3} & 23.3 & 99.4 \\
\hline & \multicolumn{2}{|c|}{ Others } & 1 & \multicolumn{2}{|r|}{6} & .6 & 100.0 \\
\hline & \multicolumn{2}{|l|}{ Total } & 163 & & 0.0 & 100.0 & \\
\hline & \multicolumn{7}{|c|}{ HIGHEST QUALIFICATION } \\
\hline & & & Frequency & Percent & Val & id Percent & Cumulative Percent \\
\hline \multirow{4}{*}{ Valid } & \multicolumn{2}{|c|}{ bachelor degree } & 6 & 3.7 & & 3.7 & $\begin{array}{r}.7 \\
\end{array}$ \\
\hline & \multicolumn{2}{|c|}{ master degree } & 35 & 21.5 & & 21.5 & 25.2 \\
\hline & \multicolumn{2}{|l|}{ PhD } & 116 & 71.2 & & 71.2 & 96.3 \\
\hline & \multicolumn{2}{|c|}{ Others } & 3.7 & 3.7 & & 3.7 & 100.0 \\
\hline
\end{tabular}


Vol. 7, No.1, January 2018, E-ISSN: 2226-6348 @ 2018 HRMARS

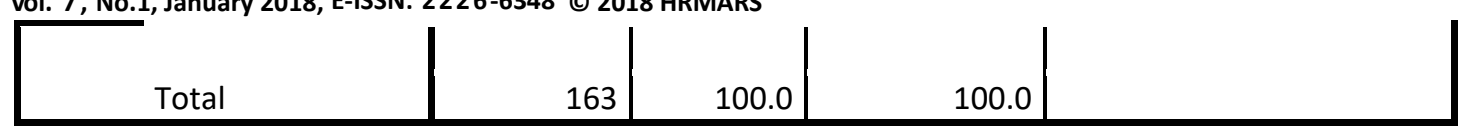

The demographic characteristics of the respondents are presented in tables $1 \mathrm{a}$ and $1 \mathrm{~b}$. The key variables of interest are: gender, years of experience, job title and highest qualification. According to the table, $41.1 \%$ and $58.9 \%$ account for male and female respectively in the analysis regarding gender. For years of experience, $14.1 \%$ account for $<5$ years, $27 \%$ account for $5-9$ years, $30.7 \%$ account for $10-14$ years and $27.6 \%$ account for $>15$ years. The analysis on job title reveals that $4.3 \%$ are professors, $15.8 \%$ are associate professor, $56.4 \%$ and $23.3 \%$ account for assistant professor and lecturer respectively. While $6 \%$ account for other job titles. Regarding highest education, $3.7 \%$ and $21.5 \%$ account for bachelor and master degree respectively. Doctoral degree (PhD) accounts for $71.2 \%$ while other academic qualification account for $3.7 \%$.

\section{Measurement Model Fit}

The chi- Square test $\left(\mathrm{X}^{2}\right)$ is used to evaluate the goodness- of- fit of a model. This test statistic checks a null hypothesis to ascertain if a proposed or hypothesized model fitted the data collected (Fornell and Larcker, 1981). When $X^{2}$ is statistically significant (i.e $p<0.05$ ), the conclusion is reached that the model does not adequately fit the data collected and such model is deemed unacceptable. The reverse is the case with $X^{2}$ that is not statistically significant. On the basis of the $X^{2}$ indices presented in table 2, we are driven to contend that the proposed model adequately fit the data collected because the probability level associated with the $X^{2}$ is higher than the $p$ - value. The indices of interest are $\left.:\left\{X^{2}=(C M I N)=10.723 ; D F=6 ; P>.05\right)\right\}$.

Table 2: Measurement Model Fit

\begin{tabular}{|l|rrrrr|}
\hline Model & NPAR & CMIN & DF & P & CMIN/DF \\
\hline Default model & 39 & 10.723 & 6 & .097 & 1.787 \\
Saturated model & 45 & .000 & 0 & & \\
Independence model & 9 & 907.524 & 36 & .000 & 25.209 \\
\hline
\end{tabular}

To ensure consistency of a researcher's judgment concerning model fit, absolute indices such as Goodness-of-Fit Index (GFI) and Root Mean Square Error of Approximation (RMSEA) are further examined. Additionally, incremental fit indices such as the Normed Fit Index (NFI) and Comparative Fit Index (CFI) were looked at to strengthen our judgment regarding the structural fit of the model. See table 3 to 5 . With the exclusion of RMSEA, an incremental fit index>.90 indicates acceptable model fit (Hayduk, 1987). And a RMSEA index of .05 is seen as close fit and a value $>.08$ is perceived as reasonable fit (Browne and Cudeck, 1993; Byrne, 2001). The values in table 3,4 and 5 are within the acceptable threshold levels. Specifically, GFI= .986; NFI= .988; $\mathrm{CFI}=.995$; $\mathrm{RMSEA}=.070$. These results further suggest that the proposed model is congruent with the data collected.

Table 3: Root Mean Square Residual and Goodness-of-Fit-Index

\begin{tabular}{|l|rrrr|}
\hline Model & RMR & GFI & AGFI & PGFI \\
\hline Default model & .015 & .986 & .893 & .131 \\
\hline
\end{tabular}


INTERNATIONAL JOURNAL OF ACADEMIC RESEARCH IN PROGRESSIVE EDUCATION AND DEVELOPMENT

Vol. 7, No.1, January 2018, E-ISSN: 2226-6348 @ 2018 HRMARS

\begin{tabular}{|l|rrrr|}
\hline Model & RMR & GFI & AGFI & PGFI \\
\hline Saturated model & .000 & 1.000 & & \\
Independence model & .350 & .291 & .113 & .232 \\
\hline
\end{tabular}

Table 4: Baseline Comparisons

\begin{tabular}{|l|rrrrr|}
\hline Model & $\begin{array}{r}\text { NFI } \\
\text { Delta1 }\end{array}$ & $\begin{array}{r}\text { RFI } \\
\text { rho1 }\end{array}$ & $\begin{array}{r}\text { IFI } \\
\text { Delta2 }\end{array}$ & $\begin{array}{r}\text { TLI } \\
\text { rho2 }\end{array}$ & CFI \\
\hline Default model & .988 & .929 & .995 & .967 & .995 \\
Saturated model & 1.000 & & 1.000 & & 1.000 \\
Independence model & .000 & .000 & .000 & .000 & .000 \\
\hline
\end{tabular}

Table 5: Root Mean Square Error of Approximation

\begin{tabular}{|l|rrrr|}
\hline Model & RMSEA & LO 90 & HI 90 & PCLOSE \\
\hline Default model & .070 & .000 & .136 & .265 \\
Independence model & .387 & .365 & .409 & .000 \\
\hline
\end{tabular}

\section{Structural Analysis}

The proposed model was acceptable on the bases of $X^{2}, \mathrm{GFI}, \mathrm{NFI}, \mathrm{CFI}$ and RMSEA coefficients. The acceptance of the proposed model encouraged the researchers to embark on structural analyses of the model. Specifically, the researchers seek to ascertain the statistical significance of the coefficients which are associated with the paths in the model. See figure 2 for the proposed model and its estimated parameters.

Figure 2: The estimated parameters of the Proposed Model 


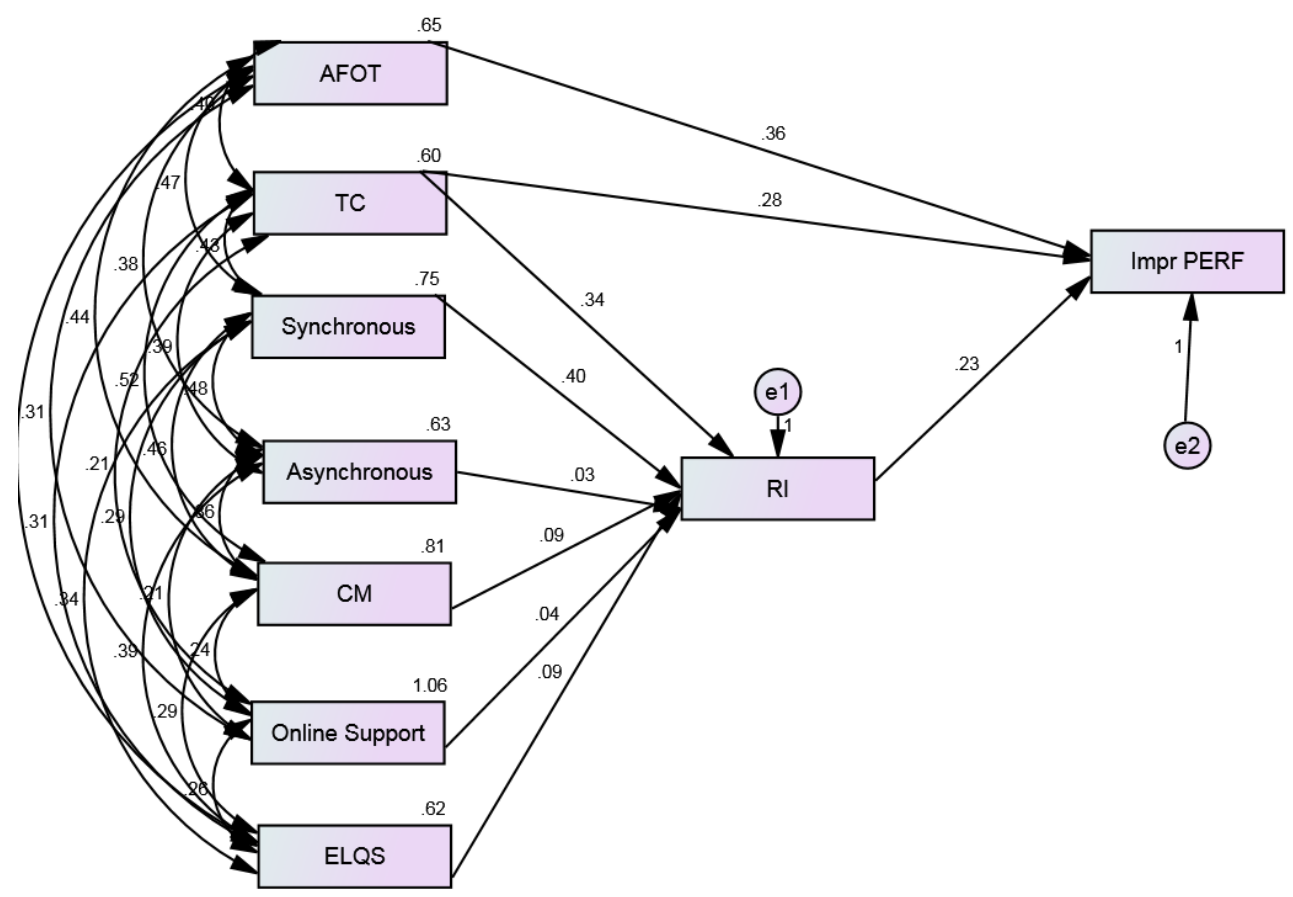

The standardized regression weights and their corresponding $p$-values were used to assess the impacts of the exogenous variables on the endogenous variables and that of the mediating variable on the endogenous variable. See table 5 and 6 . According to the tables, SYN and TC have positive significant impacts on RI. The standardized path coefficient and the associated $p$-value for SYN to RI is (SYN=.384, p<0.000) and for TC to RI is $(T C=.294, p<0.000)$. These results suggest that the two exogenous variables are good predictors of RI. Furthermore, RI has positive impact on PERF_ACAD_STAFF. The standardized path coefficient and its corresponding $p$-value is (RI= .247, $\mathrm{p}<0.001)$. This means that the mediating variable (RI) has significant impact on PERF_ACAD_STAFF. AFOT and TC have direct positive impacts on PERF_ACAD_STAFF. The standardized path coefficients are $(\mathrm{AFOL}=.352, \mathrm{p}<.0 .000 ; \mathrm{TC}=.260, \mathrm{p}<0.000)$. These results showed that the two exogenous variables have direct significant positive impacts on PERF_ACAD_STAFF. Also, it is estimated that the predictors of RI explained 59 percent of its variance while the predictors of PERF_ACAD_STAFF explained 56 percent of its variance. See squared multiple correlation coefficients $\left(R^{2}\right)$ in table 6 .

Table 5: Regression weights

\begin{tabular}{|c|c|c|c|c|c|c|c|}
\hline & & & Estimate & S.E. & C.R. & $P$ & Label \\
\hline RI & $<---$ & SYN & .401 & .081 & 4.923 & $* * *$ & par_1 \\
\hline RI & $<---$ & OS & .040 & .048 & .830 & .406 & par_3 \\
\hline RI & $<---$ & ASYN & .028 & .092 & .307 & .759 & par_4 \\
\hline RI & $<---$ & CM & .092 & .077 & 1.194 & .233 & par_5 \\
\hline RI & $<---$ & ELQS & .092 & .077 & 1.204 & .229 & par_6 \\
\hline
\end{tabular}


INTERNATIONAL JOURNAL OF ACADEMIC RESEARCH IN PROGRESSIVE EDUCATION AND DEVELOPMENT

Vol. 7, No.1, January 2018, E-ISSN: 2226-6348 @ 2018 HRMARS

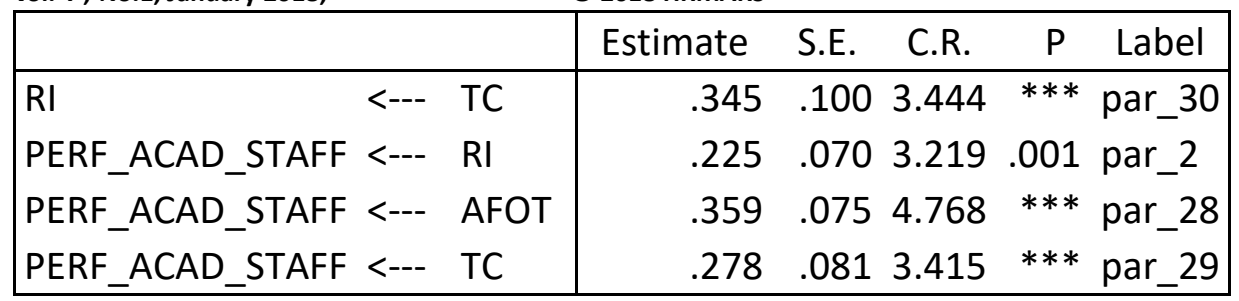

\section{Table 6: Standardized Regression weights}

\begin{tabular}{|c|c|c|c|}
\hline & & & Estimate \\
\hline RI & $<---$ & SYN & .384 \\
\hline RI & $<---$ & OS & .045 \\
\hline RI & $<---$ & ASYN & .025 \\
\hline $\mathrm{RI}$ & $<---$ & $\mathrm{CM}$ & .092 \\
\hline RI & $<---$ & ELQS & .080 \\
\hline RI & $<---$ & $\mathrm{TC}$ & .294 \\
\hline PERF_ACAD_STAFF & $<---$ & $\mathrm{RI}$ & .247 \\
\hline PERF_ACAD_STAFF & $<---$ & AFOT & .352 \\
\hline PERF_ACAD_STAFF & $<---$ & $\mathrm{TC}$ & .260 \\
\hline
\end{tabular}


INTERNATIONAL JOURNAL OF ACADEMIC RESEARCH IN PROGRESSIVE EDUCATION AND DEVELOPMENT

Vol. 7, No.1, January 2018, E-ISSN: 222 6-6348 @ 2018 HRMARS

Table 6: squared multiple correlation coefficient $\left(\mathbf{R}^{2}\right)$

\begin{tabular}{|l|r|}
\hline & Estimate \\
\hline RI & .590 \\
PERF_ACAD_STAFF & .560 \\
\hline
\end{tabular}

\section{Implications, Recommendations and Conclusion}

The objective of the study was to examine the impact of E-learning on the performance of academic staff of King Khalid University. The results facilitated the rejection of five hypotheses such as: $\mathrm{H1}, \mathrm{H} 2, \mathrm{H} 3, \mathrm{H} 4$ and $\mathrm{H} 9$ However, the study confirmed that acceptance for online teaching (AFOT), Technical competency (TC) and synchronous (Sync) lectures have indirect influence on performance of academic staff (PERF_ACAD_STAFF). Furthermore, acceptance for online teaching (AFOT) and Technical competency (TC) have direct impact on performance of academic staff (PERF_ACAD_STAFF). The outcome of the hypotheses lead to the development of the empirical model (see figure 3 ) and we recommend that the model should guide the management of KKU in designing their $E$ learning initiatives. 


\section{Figure 3: The Empirical Model}

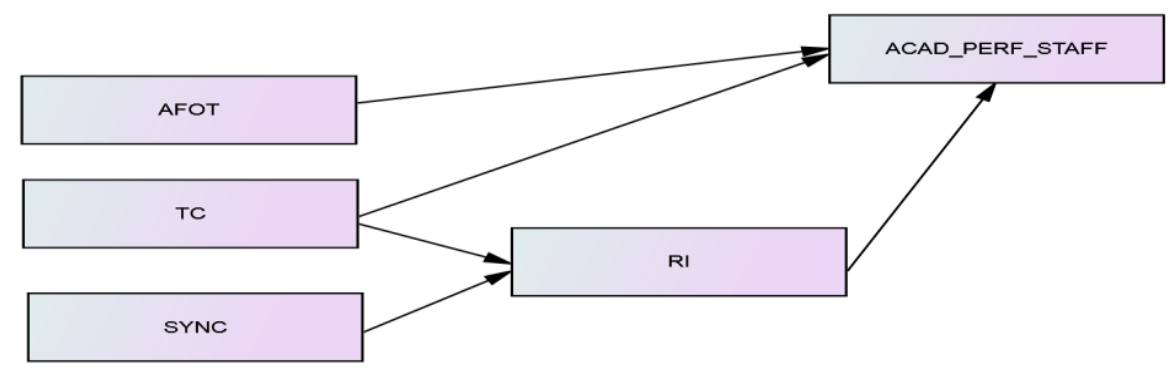

On the basis of the results, we recommend that the management of KKU should ensure that potential learners of the university accept to learn through web- based technology. In addition, the management of the university should certify that learners and instructors have the required technical competency. Furthermore, the teachings should occur in real time. These recommendations when perused can potentially increase the level of performance of academic staff in their course delivery activities.

We concluded that our empirical model should guide KKU in designing its E-learning initiatives in that it will enable students at KKU to achieve similar learning outcomes that are comparable to traditional classroom format. 
INTERNATIONAL JOURNAL OF ACADEMIC RESEARCH IN PROGRESSIVE EDUCATION AND DEVELOPMENT

Vol. 7, No.1, January 2018, E-ISSN: 2226-6348 @ 2018 HRMARS

\section{References}

Alavi, M., \& Leidner, D. E. (2001). Technology-mediated learning- A call for greater depth and breadth of research. Information Systems Research, 12 (1), 1-10.

Barker, K., \& Wendel, T. (2001). E-Learning: Studying Canada's virtual secondary schools. Kelowna, BC: Society for the Advancement of Excellence in Education. Retrieved December 27, 2016, from http://www.saee.ca/pdfs/006.pdf

Breuleux, A., Laferrière, T., \& Lamon, M. (2002). Capacity building within and across countries into the effective uses of ICTs. Paper presented at the 2002 Pan-Canadian Education Research Agenda Symposium, Montreal, QC. Retrieved March 27, 2017 from http://www.cesc.ca/pcera2002E.html

Browne, M.W. \& Cudeck, R. (1993). Alternative ways of assessing model fit. In Bollen, K.A. \& Long, J.S. [Eds.] Testing structural equation models. Newbury Park, CA: Sage, 136-162.

Byrne, B. M. (1994). Structural equation modeling with EQS and EQS/Windows. Thousand Oaks, CA: Sage Publications.

Cavanaugh, C.S. (2001). The Effectiveness of Interactive Distance Education Technologies in K-12 Learning: A Meta-Analysis. International Journal of Educational Telecommunications, 7(1), 73-88. Norfolk, VA: Association for the Advancement of Computing in Education (AACE).

Chambers, E. A. (2003). Efficacy of educational technology in elementary and secondary classrooms: A meta-analysis of the research literature from 1992-2002. Ph.D. dissertation, Southern Illinois University at Carbondale. Retrieved December 27, 2016 from ProQuest Digital Dissertations database. (Publication No. AAT 3065343).

Clark, R.C., \& Mayer, R.E. (2008). Learning by viewing versus learning by doing: Evidence-based guidelines for principled learning environments. Performance Improvement, 47, 5-13.

Downes, S (2005). Semantic networks and social networks. The Learning organization, Vol 12 Issue 5, pp 411-417

Ettinger, A., Holton V., \& Blass, E. (2006) "E-Learner Experiences: A Lesson on In-House Branding," Industrial \& Commercial Training, Vol. 38, No. 1, pp. 6-33.

Fornell, C., \& Larcker, D. F. (1981). Structural Equation Models with Unobservable Variables and Measurement Error: Algebra and Statistics. Journal of Marketing Research, 18, 382-388. http://dx.doi.org/10.2307/3150980 
Hardaker, Glenn and Smith, David C. (2000) elearning innovation through the implementation of an internet supported learning environment. Journal of educational technology and society, 3 (3). pp. 422432. ISSN 14364522

Hayduk, L. A. (1987). Structural equation modeling with LISREL. Hillsdale, NJ: Lawrence Erlbaum Associates.

Herrington, J., Reeves, T.C. and Oliver, R. (2010) A Guide to Authentic eLearning. Routledge, New York

Johnson, G.M. (2005). Student Alienation, Academic Achievement, and WebCT use. Educational Technology and Society, 8, 179-189

Kearsley, G. (2000). Online education: learning and teaching in cyberspace. Belmont, CA: Wadsworth.

Liaw, S. S. (2008). Investigating students' perceived satisfaction, behavioral intention, and effectiveness of e-learning: A case study of the Blackboard system. Computers \& Education, 51(2), 864-873.

Liu, X., Magjuka, R. J., Bonk, C. J., \& Lee, S. (2007). Does sense of community matter? An examination of participants' perceptions of building learning communities in online courses. Quarterly Review of Distance Education, 8(1), 9-24

Rosenberg, M. J. (2006). Beyond e-learning: Approaches and technologies to enhance organizational knowledge, learning, and performance. San Francisco: Pfeiffer

Roy, K. (2006). The impact of learning styles on interactivity in asynchronous e-learning. Perf. Iprov., 45: 21-26.

Tavangarian, D., Leypold, M. E., Nölting, K., Röser, M., \& Voigt, D. (2004). Is e-Learning the solution for individual learning? Electronic Journal of e-Learning, 2(2), 273-280. 